Kom, 2020, vol. IX (1) : 51-69

UDC: 284

DOI: $10.5937 /$ kom $2001051 \mathrm{~A}$

Original scientific paper

\title{
The Status of Reason in Shia Thought AND UNDERSTANDING OF ISLAM
}

\author{
Amanallah Alizadeh \\ Faculty of Philosophy, Al-Mustafa International University, \\ Qom, I. R. Iran
}

\begin{abstract}
Reason has nonpareil role both for making the components of cognition and obtaining divine knowledge in Shia schools of thought. In epistemology, we would have very few certain prepositions which could be comprehended without mediation of intellect. It is intellect with which foundation of cognition will be formed and the constituents of cognition will be built. In obtaining divine knowledge, it also has a unique function alongside the holy book, tradition, intuition and consensus. Because of the crucial role of reason in Shia school of thought, scientific currents are more rational comparing to Sunni. Schools of philosophy, rational theology, exegeses and principles of jurisprudence are advent in Shia cultural context. We can even say: moderate rationality is the main stream of Shia current that is far from Akhbarits and Tafkiki School, which are exceptional in Shia school of thought. Therefore, religious beliefs, moral values and practical commandments in Shia thinking are more rational. Although reason and rational thoughts were not so important at the time of the Infallibles because they were considered as manifestation of truth, at the occultation age, reason obtained its necessity alongside the text. Thus, it can be said: moderate rationality is an outstanding feature of Shia in Islamic history.
\end{abstract}

Keywords: reason, status of reason, thought, Shia, intellectual cognition, moderate rationality

\section{Introduction}

Reason is one of the most significant tools of human being for obtaining knowledge among five senses, imagination, fantasy and intuition and is

Corresponding author: alizadehamanallah@gmail.com 
a reliable one for attaining divine knowledge. The importance of intellect is truly for this reason to know whether what we obtain is truth, illusion or mirage. The necessity of discussion about status of intellect in religious knowledge refers to this reason to know whether man's instrument for getting divine knowledge is authentic and safe from error or not, because if we do not know how we grasp knowledge and how cognition constitutes, we will consider all illusion and mirage as cognition. Now, if we look for truth with detected instrument and defensive mechanism of cognition, we will waste our whole life of time to achieve truth, but never access it. Since the knowledge which we obtain through intellect is acquired knowledge, we should verify the role of intellect as an instrument for acquiring concepts, propositions in epistemology because we need to now the structure of our cognition and then we should clarify the status of intellect in Islamic thought based on Shia cultural context. Therefore, what would be analyzed is the role of intellect for constitution of certain cognition and the status of reason in Islamic sciences throughout history. The consequence of investigation would be praiseworthy because we would understand how beliefs, moral values and practical commandments are rational and how intellect has a role for generations of them.

\section{1. Definition of Intellect}

We should consider that intellect has different meanings in Greek culture and in Islamic culture. In Greek culture, it means to know nature while in Arabic Islamic culture reason is considered as a criterion for distinction of good deeds from the bad ones (Karami 2001: 241). When it is derived in book of Lisan al-Arab from the word "Iqal" (camel's shackle), which is a synonym for forbidden and opposite of praiseworthy, it truly refers to moral and valuable aspects because, just like "camel's shackle" prevents camel from going away, intellect prevents mankind from getting into difficulties and troubles (Ibn Manzur 1956: X/459). If some scholars consider this type of intellect as a reason for the decline of Islamic culture and civilization, they do not see any creativity in this kind of intellect to culminate to generation of new things because reason in this perception is more moral conduct than intellectual activity that discovers and explains the universe (Karami 2001: 242).

In this writing, we neither consider the Greek meaning of intellect, which is synonymous with Logos and Nous that aim to discover the Nature of Universe, nor Arabic perception of intellect which is considered as a standard for distinguishing good deeds from the bad ones, which has a more moral aspect. What I intended from reason and intellect in this writing is the inner faculty of the soul and man's power for obtaining knowledge among 
five sense, imagination, fantasy and intuition that is utilized to discover and illustrate the structure of Universe and essence of human being. We can say that what Allamah Tabatabai said in his Tafsir al-Mizan about intellect is close to this meaning. He maintains that intellect is a human power that distinguishes between true and false in theoretical affairs, good and evil, harm and advantage in practical affairs (Allamah Tabatabai 1969: 373).

\section{2. Definition of Thought}

The "thought" is an interdisciplinary concept that is explained in various sciences such as philosophy, ethics, logic and mysticism. The term of thought in philosophy and logic is used for mental activities and process of man when he faces a problem and tries to manage his/her knowledge to solve that and achieve a new mental representation (Abbasi 2008: 54), but that is not intended in this writing because it in itself is a "state of thinking". What I intended in here from the term of thought is a collection of notions and cognitions which are gathered in a system of thinking and schools of thought that is called "Shia thought".

\section{Intellect as Man's Cognitive Instrument}

\section{1. The Role of Intellect in Obtaining Concepts}

The fundamental point, which needs to be verified in here, is the role of intellect in the formation of certain cognition for mankind. To know that, we should ponder on Islamic epistemology that divides man's knowledge into two types: knowledge by presence and acquired knowledge. Because of the infallibility and limitation of knowledge by presence of humankind, it will not be verified in this research. What is intended to be analyzed in this writing is acquired knowledge because the most man's knowledge such as philosophy, mathematics and natural sciences is constituted from acquired knowledge. Thus, we should realize the instrument of conceptual knowledge, origin of proposition and know how man achieves those propositions (Hosseinzadeh 2005: 39-40).

In acquired knowledge, which is presented in the form of proposition and is, in fact, an instrument for explanation of human cognition, we should discuss concepts that constitute propositions and propositions themselves. Firstly, it is vital to talk about role of intellect in formation of concepts and howness of formation of propositions from concepts. Islamic logicians divide acquired knowledge into smaller components (concepts and theorems) and continue their verifications. The concepts are mental perceptions which 
narrate from outside of mind such as concept of soul, human and concept of tree, but theorem and admission are adjustments of unity or in unity of premises and predicates. For example, the earth is circular or a human being is not a mountain (ibid: 55).

In Islamic attitude generally and in Shia attitude particularly, concepts, which form propositions, are general or particular. Particular concepts are sensory, imaginary or illusory which are not intended in this essay, but intellect has crucial role for obtaining general concepts such as essential concepts, philosophical concepts and logical concepts. They are attained by reason. Consider essential concepts. First, we get concepts through five senses, then keep them in our imagination faculty and finally our intellect generalizes those concepts:

First, five senses observe facts that are located in front five senses, then man's imagination faculty gets partial concept from that and finally this partial concepts reflect in intellect. Consequently, general concepts appear in the mind, which we call primary concepts or essential concepts (ibid: 74).

In the second type, essential concepts are obtained through partial concepts that are not sensory concepts, but rather they are partial concepts that narrate from knowledge by presence; like, concept of "fear" that mankind understands without an intermediate concept. Finally, intellect generalizes the concept of Fear (ibid: 75).

However, logical and philosophical secondary concepts do not need such a process because intellect, without such abstraction and generalization, attributes concepts to qualification. Thus, logical secondary concepts are attributes of mental concepts such as Generality for concept of Human, that is, the concept of human indicates to all mankind equally, but the philosophical secondary concepts are attributes of outer things such as Causality for Fire that burns wood (ibid: 79). These three concepts (essential, logical and philosophical) have a commonality in that they are obtained by intellect and attributed to mental and outer existents. Therefore, it seems impossible to access general concepts without intellect.

\section{2. The Role of Intellect in Confirmation of Proposition}

Now, one thing, which remained to be verified in this part, is to know the role of intellect in constitution of propositions that are formed by partial and general concepts. We do not really understand the function of reason 
in religious propositions unless we realize the role of it in propositions from epistemological approach. It is vital to analyze all types of propositions in Islamic logic, so as to comprehend the status of reason in religious propositions. Propositions are generally divided into self-evident propositions and theoretical propositions. The self-evident ones are divided into primary and secondary propositions.

Primary self-evident oppositions do not need five senses to have confirmation because the concepts in there are general, so the confirmation in a proposition takes place by intellect (ibid: 100). For instance, the principle of "non-contradiction", or "impossibility of offending effect from cause", "the principle of it-is-it-ness" and "the whole is bigger than part" are completely comprehended by intellect, that is, self-evident propositions have this characteristic that confirmation that is on them is more than their parts (Hosseinzadeh 2016: 35).

In all secondary self-evident propositions such as "sense perception", "intuitive cognition", "conjectures", "experiments", "inherent" and "successive propositions" intellect has the main role for confirmation or rejection. For instance, in sensory prepositions, the correspondence between concepts and existents in external world is impossible by five senses, so we need intellect to do the correspondence (Hosseinzadeh 2005: 102); likewise, experimental propositions need reason for proving examples in external world (ibid). Such are intuitive propositions, which confirm a proposition by the help of intuitive data, that is, knowledge by presence prepares the situation for confirmation. However, in conjectural propositions, where the major premise appears in the mind without thinking, intellect has the main role because there is hidden reasoning which needs arguing that is possible only by nous. Thus, the conjectural propositions need intellect for both hidden arguments and relying on conjecture (ibid: 103). Such condition exists in inherent propositions, that is to say, the major premise is present in mind, but its confirmation needs arguments. The necessity of successive propositions for intellect is more than for others because they have double necessity to nous. Both premises are general predicates that are obtained by intellect and confirmed by intellect.

Therefore, in self-evident propositions, both primary and secondary, cognition is obtained by intellect. Without the interference of intellect, cognition for human beings would not be possible.

\section{Intellect as an Instrument or Source of Cognition}

Intellect has various meanings, but whether we consider it as an instrument or source, it is a rational faculty and human power that we utilize for 
obtaining knowledge. When we talk about intellect in philosophy or logic, we aim exactly at the same meaning for intellect that we get concepts and confirmation and make propositions and argumentation. Propositions and arguments are constituted from essential concepts, logical, and philosophical concepts and we arrange notions and knowledge by intellect to discover unknown issues. Thus, we are in need of nous to understand such propositions and arguments and we are in need of comprehending credibility and authenticity of intellect, which has such valuable functions for attaining cognition and religious teachings in Shia understanding of Islam. There were various opinions relating to rational faculty of mankind. Mutazilites considered intellect as criteria for religion; so they rejected what intellect denies and accepted what intellect admits. Contrary to Mutazilites, Asharites rejected the interference of reason in religious understanding because Asharites maintained that Islam is a prefect religion which provides cognition-necessity of mankind up to resurrection. Islamic dignitaries like, Prophet Muhammad, infallible Imams, companions and scholars explained and interpreted Islamic teachings in a way that there was no need for intellect to discover unknown religious issues. In Shia understanding of Islam, there are two approaches referring to intellect - moderate and inattentive approaches. Akhbaris and members of Tafkiki School have inattentive approach, but majority of Shia have moderate approach regarding intellect, that is, both intellect and texts (holy book and traditions) are necessary for discovering religious commandments or explaining religious doctrines. Thus, firstly, it is vital to verify two inattentive approaches of Traditionalists and members of Tafkiki School. Secondly, it is crucial to deliberate the basic moderate approach of Shia.

\section{1. Akhbari School (Traditionalism)}

It seems incredible that Akhbaris arose in Shia school of thought because it seems impossible that a type of thinking that ignores rationality and considers it useless should appear in Shia, which emphasizes rationality. The primary perception of traditionalism is that they refuse intellect as a religious cognitive instrument and maintain that the Quran, Traditions and Precaution suffice for obtaining religious doctrines. However, it seems shallow relating to them because traditionalists certainly saw address of the Quran referring to Thinking and surely verified narration of Usul al-Kafi and other religious resources connection to nous. It seems that they cannot have had such a point of view in Shia rational and cultural context. Thus, it needs to be verified what they aimed from reason and what status they believed intellect had.

Akhbaris thoughts had roots in textualism that was against rationalism and were active at the time of Prophet Muhammad and Infallible Imams. 
The most prominent among them were Imam al-Baqir and Imam al-Sadiq's companions, who were renowned theologians and Traditionalists. Hisham ibn Hakam, Hisham ibn Salim, Hamran ibn A'yun, Muhammad Tayyar and Mu'min at-Taq were representatives of the first group and Muhammad Muslim, Ahmad ibn Muhammad ibn Khalid Buri, Muhammad ibn Hasm al-Saffar were representatives of the second group (Sobhani 1995: 217).

In $12^{\text {th }}$ and $16^{\text {th }}$ centuries, Razi al-Din Ali ibn Tawus and Zain al-Din Ali ibn Ali ibn Ahamad Amili, who was well-known to Shahid al-Thani, were two representatives of textualism who continued alongside rationalism (ibid: 225). This approach was continued by Shaykh Hurr Amili and Muhammad Baqir Majlisi when it reached its zenith. Muhammad Amin Astarabadi shifted it to a school of thought by the name of Akhbaris (ibid: 227).

Muhammad Amin Astarabadi who was the founder of Akhbaris, did not put aside reason in all dimensions of life and cognition, but he limited nous in practical commandments and jurisprudence. Nonetheless, his followers expanded limitation and worthlessness of intellect into the arena of beliefs and morality. Astarabadi, in his book Kitab al-Fawaid al-Madaniyya wa al-shawahid al-Makkiyya, which is his most important book for rejecting Usuliyyin and theologians, did not have a clear and distinguished definition of intellect, but we can infer from the content of his sayings that intellect in his opinion was "inner faculty of human being".

All philosophers, theologians and Usuliyyin adopted it; however, what distinguished his notion from the main stream of Shia is his epistemology. He defined self-evident propositions in another way. He divided knowledge into two types: certain knowledge and surmise. Certain knowledge is a knowledge that combines fragments that are close to sensory, such as geometry, mathematics and some part of logic (Astarabadi 2005: 256).

The second type of knowledge is the sciences that are formed from fragments that are far from sensations, such as philosophy, natural science, theology, principles of jurisprudence and logic. Based on his opinion, there are various disagreements among scholars. The reason is clear, because logic rules prevent thought and mind from committing mistakes and logicians utilize truly from that because they are aware of that, but they would have disagreement because they use uncertain materials for constituting propositions (ibid: 256-257). He believes in inefficiency of intellect in the case of propositions formed from materials that are not close to sensation. It does not mean that he rejects nous thoroughly. No, he believes in reliability of nous in everyday life and ordinary affairs, but rejects its reliability in Sharia, like theology, principles of jurisprudence, jurisprudence (al-Fiqh) and philosophy, which are surmises and unauthentic (Rezwani 2009: 189). The most important reason for inefficiency of intellect in obtaining religious cognition is that: 
In Akhbari schools of thought, what Islamic nation needs up to resurrection day is revealed from Allah with certain reasons. Most of commandments that were revealed to Prophet Muhammad and that relate to the Quran and traditions like abrogation, determination and exegeses exist among infallibles. The Quranic teachings and most of the Prophet's traditions seem general for common people and we have no way to access divine commandments (principles or branches) except through honest and truthful infallibles. It is not allowed to infer theoretical commandments from the Holy Book and narrations except from possessor of remembrance. Thus, we are obliged to halt and have to do precaution. If Jurists make mistake in abstraction of divine laws, they attribute it to untrue saying to God and have no reward if they have true inferring (Astarabadi 2005: 104).

Therefore, Akhbaris, continuing textualism and traditionalism, do not value intellect for obtaining religious cognitions because they believe in perfection of Islamic religion that is explained by Prophet Muhammad and infallible Imams up to resurrection. We are not in need of any other resources to illustrate our necessities. When we are confronted with a case that is not explained in commandment by the Quran and Tradition, the solution is precaution. We do not need intellect for such a condition to attain religious doctrines, but in private and social life, we utilize intellect. It is authentic and beneficial.

\section{2. Tafkiki School}

The second current in Shia that has negligent approach to intellect is Tafkiki School. There are radical and moderate interpretations relating to Tafkiki School. Mirza Mahdi Esfahani is a representative of the radical one and Muhammad Rida Hakimi is a representative of the latter. The thing the two interpretations have in common is that they both maintain in to two types of intellects; luminous intellect which is divine reason and eclectic reason (iltiqati) which is satan's reason. There is also a differentiation between the radical approach, which considers reason as deviation, misguidance and does not value and respect nous, and the moderate interpretation, which values and respects reason. Although intellect has value and respect in moderate approach, they do not consider intellect as an appropriate instrument for attaining religious knowledge; they do not recommend going toward the Quran and tradition by rational attitude. In his book Abwab al-Huda, Mirza Mahdi Esfahani, a prominent figure of the radical approach of Tafkiki School, clearly distinguishes between two types of reason. He considers one as divine reason and the other as satanic reason: 
The intellect that is divine reason, is different from the intellect that is satan's reason. The second one is mere sophistry, deviation and ignorance. As it has been mentioned previously, the argument is the basis of disagreement among individuals that can be shown in human's behaviors. If a legislator establishes his arguments based on reasoning, this argument will not eliminate disagreement; however, intellect is a status of prophet (Esfahani 2008: 149).

We can deduce from his assertion, here and in some other places, that he does not believe basically in intellect and value of argument. He even considers reasoning for proving of Allah to be against principles of religion and counts it abolition (Javadi Amoli 2007: 111).

There is also a differentiation between "inherent intellect" and "analytic intellect" in the moderate interpretation of Tafkiki School. Supposedly, they understand religious teachings by inherent intellect not analytic one. While human inherent intellect is captivated by his/her instinct, unrighteous thought and corrupted action, the inherent intellect won't be activated. Inner intellects will be activated if human inherent intellect is released from fetters and chains. Muhammad Rida Hakimi explains in his book Tafkiki School:

The revelation puts special emphasis on thinking and activating of reason, but real thinking is not imagination and fantasy. Real thinking is pondering by "luminous intellect" which is activated thoroughly by adopting, performing religious doctrines and retrieving to inherent intellect. In fact, there is an active intellect - but captive - within every human being. Whenever our inherent intellect is hidden under the curtain of instinct, false action, deceitful thought, expression and concept, intellect will be enslaved and will not become active. When inherent intellect gets free, intellect becomes active (Hakimi 2014: 163).

Contrary to the above-mentioned intellect, he presents another intellect which is praiseworthy in their thought and does not deny the status of nous and analytic reason, but should not be used for comprehending the Quran and traditions, so that religious knowledge remains pure and stays far away from access of intellect (Javadi Amoli 2007: 111). Thus, Hakimi highlights that we should not understand Quranic sciences and essence of such doctrines by such intellect:

There must be some awareness and powerful scholars to stand against flood of eclecticism and interpretation, and do not mix Quranic doctrines with Greek philosophy and mysticism which draw from Alexandrian, 
Indian and so on. These scholars have to keep these philosophical schools away from Quranic sciences and essence of Quranic knowledge and in that manner they will save independents of Quranic schools. Whoever wants to know pure Quranic point of view without alteration, interpretation, eclectics and intermix, must approach so (Hakimi 2014: 74).

Therefore, Tafkiki School as a second negligence current in Shia history, believes in separation and segregation between inherent intellect and analytic intellect. They do not believe in credibility and reliability of the analytic one for attaining religious knowledge because it is satanic reason and the basis of deviation, aberration and dispute. Devine knowledge can be attained with inherent intellect.

\section{3. The Moderate Rationalist Approach of Maximum Shia}

Contrary to the two pervious approaches, there is a predominant approach of Shia scholars who believe in moderate rationality. They authorize revelation and reason together. This moderate approach relating to intellect constitutes the basic Shia thought. They neither neglect reason for comprehending religious doctrines as Ahl al-Hadith and Akhbaris do, nor do they introduce reason as a sole critetion for understanding religious commandments. They value both of them together. That is why philosophical, theological, mystical thoughts and exegeses and Quranic interpretation are more rational in Shia thought. Reason and rationality approach cause firmness and coherence among Shia thought.

\section{Appearance and Expansion of Philosophical Thought in Shia}

Praising intellect and rationality in Shia thought led to adapting and developing philosophical thoughts. The interaction of Shia scholars with Infallible Imams led to the constitution of distinct philosophical anthropology and different philosophy in Shia circumstance. At the beginning of revelation, Muslims and particularly Shia did not were not familiar with free thinking of philosophy, but they were familiar with Shia leaders' speeches and thoughts. Unlike Mu'tazilites, who rely upon intellect more than Shia for obtaining religious teachings, their philosophy did not have richness and progress. The history of philosophy in Islamic world shows that great philosophers appeared in intellectual and cultural context of Shia and made rational changing and evolution. Allamah Tabatabai explicitly said in his book Shia in Islam: 
The Shia was influential in advent of philosophical thought from the beginning and had fundamental role for progress and prevalence of it. They continually help the development of philosophical thought, as opposed to disappearing philosophical thought among Sunni by the demise of Ibn Rushd (Averroes); however, it was not wiped out from Shia school of thought. The prominent figures, such as Khajeh Nasir al-Din al-Tusi, Mir Damad and Mulla Sadra, appeared in Shia who put a lot of effort into education and writing of philosophy respectively (Allamah Tabatabai 2009: 92)

He admits importation of Greek philosophy and Syriac philosophy to Islamic world at the so-colled Translation period. Philosophical thoughts were conveyed to people through translation of Greek and Syriac books in $8^{\text {th }}$ and $9^{\text {th }}$ centuries, but Islamic philosophy came into existence by Shia scholars based on Tabatabai's point of view, and was developed by them. He pointed out some of Shia great philosophers like Abu Nasr Farabi in $10^{\text {th }}$ century, Avicenna in the early part of $11^{\text {th }}$ century, Shaykh Ishraq Suhrawardi and Khajeh Nasir al-Din al-Tusi in $12^{\text {th }}$ century, Muhammad Turkah in $14^{\text {th }}$ century and Mir Damad and Mulla Sadra in $16^{\text {th }}$ century (ibid: 90-99). They had unparalleled and distinguished function in philosophical thought in Islamic world. Peripatetic philosophy, illumination philosophy and transcendental philosophy are three greatest philosophical schools that were started by scholars who grew in cultural context of Shia and interacted with the Infallibles' thoughts. Thus, they presented a distinguished type of thought and report from Man and Universe. Madina Fadhila (or: Utopia) of Farabi, City (Madina) of Justice of Avicenna and City (Madina) of Faith of Mulla Sadra are existential reports from sociocultural context of perfect man that is required to be pondered deeply. They had profound thoughts referring to that. We rarely find among Islamic philosophers such ones that thought deeply about intellectual and cultural context of mankind to progress (Alizadeh 2013: 8, 12, 109). Still, we know that philosophy does not have presupposition to be divided to Shia and Sunni (Hanbali, Hanafi, Shafi'i and Maliki); however, we can divide it to Shia and Sunni in respect to where philosophy was constituted and with which philosophers it had scientific interaction. We can say: those philosophers who grew in the context of Shia culture and benefited from Infallibles' thoughts had a great role in Islamic history because intellect is more respected, valued and interacted with magnificent teachings of Infallible Imams. Thus, philosophy, in Shia school of thought, had its own way. Respect of reason and its freedom beside revelation and religious teachings in Shia culture did not only cause the growth of philosophy but it also caused a rational tendency of theology, exegesis, principles of jurisprudence. 


\section{Rational Theology of Shia Theology}

Shia theology, unlike Mutazila and Asharite's theology, has a moderate rational approach, that is, it neither restricts understanding of religious teachings to reason as Mutazila does (Sobhani \& Naimabadi 2016: 84), nor does it deny reason as Asharite and Ahle Hadith do. Shia theologians are textual-theorists who use rational theories and the holy text together to explain religious doctrines. They try to rationalize religious believes under auspices of verses and narrations (ibid: 85). Of course, when we say: "Shia theology has a moderate rational attitude", we are aware it does not mean Shia theology had the same approach from the beginning; rather it means that text and intellect had authenticity together, but sometimes textualism was more welcome by scholars and sometimes rationalism got more acceptance. None of them lost their statuses in the history of theology.

If we clarify the history of Shia theology, we can divide it into three distinct periods; the time of the Infallibles, the beginning of occultation, and contemporary age. During the first period, because of the Quran and the Prophet's emphasis on rationalism on one side, and speeches of the Infallibles as true incarnate on the other, there was no separation between textualism and intellectualism. Whenever theologian scholars took rational approach in their dialogues, they were criticized by the Infallibles. This attitude caused that those two current thoughts do not deny each other. In his easy "Resource of the First Shia Theology", Sobhani said referring to moderate rational theology:

The evidence shows that primary theologians had profound belief in a combination authenticity of intellect and revelation together for comprehending, explaining and defending religious teachings. They continually dealt with this type of discussion in their own method. Thus, they were under exposure of serious criticism of companions and advisedly recommendation of Infallibles. Zurarah was criticized because of his utilization of analogy; Mumin al-Taq was objected to for his extra usage of analogy. Although Hisham ibn Hakam had a brilliant capacity in rational debates, he was criticized seriously by companions and even Imam (ibid: 85).

At the time of Imam's presence, there was no tendency toward rationality, because Imam's speeches were considered as facts and truth, but in occultation age, people were inclined mentally toward criteria like intellect. Therefore, rationality increased gradually and reason found its place as an inner prophet. In the transition period of theological history, there were tra- 
ditionalism of Sheikh Saduq on one side and a rational approach of Banu Nawbakht on the other. Shaikh Mufid and Sayyid Murtaza tried to bring together textualism of Sheikh Saduq and rationalism of Banu Nawbakhat. Finally, the rational approach was embraced by scholars and made prevalent by students of Sheikh Mufid and Sayyid Murtaza.

By the advent of Khajeh Nasir al-Din al-Tusi and Allamah Hilli, Shia theology was rationalized and consolidated. Allamah Tabatabai had a profound statement referring to Nasir al-Din al-Tusi and remarked: Nasir al-Din al-Tusi was the first scholar who professionalized theology. Tajrid al-I'tiqad was his scientific masterpiece relating to theology (Tabatabai 2009: 93). This rationality approach is effected by two factors - philosophical thoughts that happened by translation of Greek and Syriac books and defense of Islamic principles (Sobhani 1995: 208), which both influenced utilization of philosophy in theology and caused Shia theology to reach its zenith. The three periods of theology science are explained clearly in the paragraph below:

The first period of theologians is the time of Imams' presence. The second period is constituted by Banu Nawbakht, Sheikh Mufid, Sayyid Murtaza and their followers. The third period was initiated by Nasir al-Din al-Tusi. Shia theology gradually intensified toward its peak and Shia theologians recognize peripatetic philosophy as a suitable form of presenting religious teachings (ibid: 225).

To conclude, when it is said that Shia theology is a rational theology, it means that reason has never been put aside in the Shia world; neither now nor at the beginning of the formation of Shia theology. They go hand in hand throughout the history of Shia. Although, at times, textualism appeared colorful and at some other times rationalism appeared as predominant, the main stream of Shia has neither rejected intellect as Asharites and members of Ahl al-Hadith did, nor has it denied text and restricted to intellect as Mu'tazilites do. When it is said Shia theology is rational, it exactly means that intellect and revelation are authentic simultaneously.

\section{Intellect as an Instrument and Source of Religious Cognition in Principles of Jurisprudence}

The status of intellect in the principles of jurisprudence is tied to Ijtihad, which has passed through three periods of time to reach its present magnitude for deducing divine commandments. In the first period, intellect and rationality were deliberately ignored for two reasons; the first reason was the presence of Imams, who were considered as magnificent authority 
for Sharia. All questions were returning to them. Thus, there was no room for arguing, rational discussion and scientific test of strength of religious doctrines (Karami 2001: 248). The second reason for irrationalism was that reasoning was observed as a "deviation from the text". Those Shias, who were observing legitimation of Imamate by the text, considered reasoning as denial and deviation of Imamate of Ali Ibn Abi Talib, who was designated by the text of Prophet Muhammad. Therefore, jurists were always frightened of opening chapter of Ijtihad and personal opinion which culminated in ignoring of the text and denial of Imamate (ibid: 256). For this reason, rational argument and Ijtihad have actually become another form of personal opinion. As it is said, in other words, in the following paragraph:

In primordial centuries of history of Islam the term which was indicating religious deduction was ra'y (personal opinion) not Ijtihad. The ra'y refers to religious commandments where there is no specific text, but jurists were adjudicating to lawful or prohibition of something according to condition and expressing their own opinions (ibid: 247).

In the beginning, Shia prominent figures and Imams were opposed to legitimacy of something such as Ijtihad and seriously criticized it (ibid: 253). This approach was a barrier to rationality finding its position in the principles of jurisprudence.

The second period of development of "Intellect" in the principles of jurisprudence began by minor occultation when jurists and narrators as deputies of Imam talked about necessity of "Ijtihad". Although Muhaqqiq Karaki abrogates Ijtihad, saying that it is synonymous with analogy, personal opinion and approbation, he talks about necessity of Ijtihad (ibid: 258). The first scholar who spoke about necessity of reason, considered it as source alongside Book and Narration and introduced it as a basis of cognition was Shia jurist, Abu Ali ibn Junaid. His notion was followed by his student Shaikh Mufid (Jannati 1991: 226). In his book Tazkiratun bi Usul al-Fiqh, he poses this question: what should the obliged do in occultation age, which had no access to Revelation and did not know the commandments of events and who should he/she address to help him/her to solve his/her quarrel? Then he replies; the duty of the obliged in such cases is to refer to Shia scholars. If they are not available, he/she should act upon intellect:

In other words, our intellect discovers commandments of some affairs if there is no Sharia text. It does not mean that intellect legislates a rule independently (Karami 2001:264). 
In this transitional period, intellect was criticized seriously by members of Ahl al-Hadith School, but it also obtained its reliability and respect. Thus, to consider intellect as an independent source for religious cognition was difficult and cost a lot. When Ibn Junaid talked about "reference of intellect", he still did not consider it as an independent source for religious cognition or at least he could not express it. For this reason, his recommendation referring to intellect in current affairs was not a religious order; rather it was a "principle of permission". Sheikh Mufid and Sayyid Murtaza both had rational approach in theology in contrast of textualism, yet they did not see possibility to present intellect as an independent source for religious cognition. If Sayyid Murtaza recommended to people to refer to intellect in cases where there was neither explicit text nor consensus, what he had in mind were Literal principles or practical principles (Usul Lafzi and Usul Amali) as a principle of permission (ibid: 267). Other jurists such as Muhaqqiq Hilli and Shahid Awwal introduced intellect as a source for religious teachings, but they thought of istishab (presuming continuation of the status quo ante), "precaution" and "principles of permission". Some jurists after Allamah Hilli and Shahid Thani decreased it to Literal principles and practical principles (ibid: 269).

The third period of intellect in jurisprudence is a period when it obtained its special authenticity. Some jurists observed it as a discovering instrument for religious teachings, but others considered it as a source for cognition and paralleled it to the holy Quran and traditions. In other words, Usuliyyin and Akhbaris disagreed about the source or instruments. Some of them introduced intellect as an instrument, while others introduced it as a source. Ayatullah Javadi Amoli maintained it was an instrument for discovering divine orders and said explicitly:

Intellect in different levels, from experimental intellect to half-abstract and pure intellect, can be a discoverer of religious doctrines and provider of cognitive rules alongside text if it obtains certainty and assurance cognitions (Javadi Amoli 2007: 33).

Some go beyond this and observe it as a source of religion alongside scripture and traditions and consider it as an inner prophet because intellect has self-evident comprehension that reason by itself achieves without any help of religious propositions (Akbarzadeh \& Mohammadrezaei 2014: 39).

In conclusion, reason in jurisprudence and principles of jurisprudence passed its development very differently comparing to philosophy and theology. In the beginning, because of Imam's presence, reason and rationality did not have authenticity, but in occultation age, scholars for their inaccessibility to Imams, deviation of narrations and advent of new affairs, showed their tendency 
to intellect. In the beginning, the necessity of intellect was considered at the level of literal-principles and practical-principles, but by the lapse of time, it became clear that it had self-evident comprehension without help of religions premises like al-mustaqillat al-aqliyyah (independency of intellect comprehension).

\section{Rational Exegesis in Shia Interpretation}

The role of intellect in Quranic exegesis can be seen in the development of exegeses science during history. The History of Quranic exegeses began at the time of the Prophet by formation interpretation of "Quran by Quran" and continued with Imams, culminating in the formation of "Narrative Exegesis" plus Quran by Quran exegesis. It reached its final step, "Rational Exegesis", in occultation age. There are many mythologies for interpretation in religious science like theologian methodology, jurisprudential methodology, and mystical methodology that scholars utilize for their particular sciences, but we do not care about them nor about objective interpretation and comprehensive interpretation. The three above-mentioned levels of exegeses are very crucial, as there are, in fact, three fundamental periods of exegeses in the history of interpretation science. You can see developments of the status of intellect in these three stages, which began from Quran by Quran to narrative interpretation and arrived at rational exegesis.

What is intended in Quran by Quran exegeses is that the meaning and purpose of verses are explained by other verses (Rezaee Esfahani 2006: 9), Prophet Muhammad used Quranic verses to interoperate another verse. The Quran by Quran method of interpretation initiated then and continued to the time of Saint Imams, companions and up to now. Tabarsi in his Majma' al-Bayan, Allamah Tabatabai in his al-Mizan, Siddiqi Tehrani in Tafsir al-Furqan, Abd al-Karim Khatib in Tafsir al-Qurani li al-Quran and Balaghi in Ala al-Rahman utilized from this method (ibid: 10).

Contrary to Quran by Quran exegesis, narrative exegesis sufficed to explain verses of Quran and their purpose by traditions in narrations. Prophet Muhammad was the first interpreter who thought Quranic interpretation to Imams, companions to use the Prophet's tradition and prior Imams to do exegeses. It continued at the time of companions. In the first period ( $9^{\text {th }}$ and $10^{\text {th }}$ centuries) interpretations of Ayyashi, Qomi and Tabarsi were constituted and in the second period ( $16^{\text {th }}$ and $17^{\text {th }}$ centuries) exegeses of al-Durr al-Manthur of Suyuti and Noor al-Thaqalain appeared (ibid: 4), but from $11^{\text {th }}$ century to $15^{\text {th }}$ century, because of rational attitude, narrative exegeses declined; by the advent of Akhbaris in $15^{\text {th }}$ century again they were revived.

The rational exegesis comparing to the two pervious types of interpretations is prevalent in recent years. However, there were rational exegeses 
at the time of the Prophet and He himself also utilized rational principles for interpretation of Quranic verses; nevertheless, in $11^{\text {th }}$ and $12^{\text {th }}$ centuries, usage of Ijtihad, intellect and considering whole dimensions of exegeses became a new method, which has continued up to now (ibid: 4). The rational exegesis, either we consider it as a rational usage of argument and rational indications for interpretation of Quranic aim or consider it as intellectual power for deducing from verses to illustrate their purpose, it is a serious approach, rational manner and coherent way among other exegeses. Tafsir al-Tibyan of Sheikh Tusi, Majma' al-Bayan of Sheikh Tabari, Tafsir al-Quran wa al-Aql of Noor al-Din Araki, Tafsir al-Quran of Mulla Sadra Shirazi and Tafsir al-Mizan of Allamah Tabatabai (ibid: 16) are examples of rational exegeses. Imam Ruhullah Khomeini showed his tendency among exegeses toward a mystical, philosophical, ethical and social exegesis as well as he showed his political and approximation approach to interpretation (ibid: 8).

\section{Conclusion}

What we have achieved from the above investigation referring to the status of intellect is that reason has nonpareil role in both formation of concepts as a cornerstone of cognition and confirmation of propositions in epistemology and in obtaining, explaining and rationalizing religious propositions. Those sciences, which are constituted in rational and cultural context of Shia, are very profound and progressive. Peripatetic philosophy, illumination philosophy and transcendental philosophy are three great schools of philosophy showing up in intellectual and cultural context of Shia. Rational theology, rational exegeses can be seen in this school of thought. Ijtihad as symbol of rationality has been prevalent in principles of jurisprudence of Shia. Therefore, the strong presence of intellect in Shia school of thought has three consequences, which are solidarity of religious teachings, rationality of religious doctrines (beliefs, moral values, and practical orders) and non-formation of radical and Takfiri currents in Shia cultural context. Thus, religion as a collection of beliefs, morality and practical orders in Shia interpretation of Islam has a very strong coherence and rational solidary that cannot be found in other religions. Religious teachings have rational justification. Due to the centrality of reason in religious teachings in the Shia tradition, religious extremism, Takfiri groups and violent currents have not grown in this intellectual and cultural context. Moderate rationalism has prevented formation of Takfiri currents in this atmosphere.

Received: March 28 $8^{\text {th }}, 2020$.

Accepted: May 22 2020. 


\section{References}

Abbasi, Waliyullah (2008), “Tafakor dar Andisheye Erfani”, Haft Aseman; Faslnameye Takhasosi Adyan wa Mazaheb 10 (2).

Akbarzadeh, Hamidali \& Mohammadrezaei, Mohammad (2014), "Naqshe Aql dar Marefate Dini wa Kastihaye an", Ensanpajuhiye Dini 10 (1).

Allamah Tabatabai, Muhammad Hussein (1969), Tafsir al-Mizan, Tehran, Entesharate eslami, $7^{\text {th }}$ edition.

Allamah Tabatabai, Muhammad Hussein (2009), Shia dar Islam, Qom, Bustane Ketab, $5^{\text {th }}$ edition.

Alizadeh, Amanallah (2013), Madineye Imani bar Mabnaye Hekmate Mota'aliyeh, Qom, Al-Mustafa International University, Faculty of Philosophy "Imam Khomeini", PhD dissertation.

Astarabadi, Muhammad Amin (2005), al-Fawaed al-Madaniyya wa al-Shawahed al-Makkiyya, Qom, Al-Nashr al-Islami at-Tabi'a li Jama'at al-Mudarrisin, $2^{\text {nd }}$ edition.

Esfahani, Mirza Mahdi (2008), Abwab al-Huda, introducing by Hossein Mufid, Tehran, Munir.

Hakimi, Muhammad (2014), Maktabe Tafkik, Qom, Dalile Mohkam, $8^{\text {th }}$ edition.

Hosseinzadeh, Mohammad (2005), Marefatshenasi, Qom, Moasseseye Pajuheshiye Imam Khomeini.

Hosseinzadeh, Mohammad (2016), "Etebare Aql az rahe Aql dar Dastgahe Mabnagarayan; Tabyeen wa Arzyabi", Pazhuheshhaye Aqliye Noween 2 (1): 31-51.

Ibn Manzur, Muhammad ibn Mukarram (1956), Lisan al-Arab, Beirut, Dar alIhya at-Turath al-Arabi.

Jannati, Mohammad Ebrahim (1991), Manabee Ejtehad az Didgahe Mazahebe Islami, Tehran, Keyhan.

Javadi Amoli, Abdullah (2007), Manzelate Aql Dar Hendeseye Marefate Dini, Qom, Isra.

Karami, Mohammad Taqi (2001), "Mahiyyat wa Wazifeye Aql dar Feqhe Shie", Naq wa Nazar 7 (3-4).

Rezaee Esfahani, Mohammad Ali (2006), "Rawesh-shenasiye Tafsire Imam Khomeini wa Jaygahe an dar Rawesh-haye Tafsiriye Fariqain”, Tolu' 5 (3).

Rezwani, Masumeh (2009), "Jaygahe Aql dar Andisheye Mulla Muhammad Amin Astarabadi ba Negah ba Ketabe al-Fawaid al-Madaniyyah", Hadithe Andisheh 7 (1): 182-201.

Sobhani, Mohammad Taqi (1995), "Nasgerayi wa Aqlgerayi dar Kalame Eslami", Naqd wa Nazar 1 (3-4): 205-232.

Sobhani, Mohammad Taqi \& Naimabadi, Hossein (2016), "Manabe'e Marefat dar Kalame Emamiyeye Nokhostin; Ruykardi Motamayez be Aql wa Wahy, Fetrat, Edrake Hessi wa Shohud", Ayineye Marefat 16 (1). 


\title{
Značaj i položaj razuma u šiitskom razumevanju islama
}

\author{
Amanalah Alizade \\ Filozofski fakultet, Internacionalni univerzitet al-Mustafa, Kom, Iran
}

Razumu se u šiitskoj misaonoj školi pridaje ključni značaj kako zbog kreiranja samog saznanja, tako i zbog uloge koju ima u procesu otkrivanja božjeg znanja. Bez podrške razuma ne bismo mogli da ponudimo odgovor na mnogobrojna pitanja iz oblasti epistemologije. Razum je zapravo osnovna platforma za izgradnju suštine i svih elemenata saznanja. U procesu otkrivanja božjeg znanja razum takođe ima jedinstvenu funkciju i svrstava se u osnovne izvore religijskog znanja kao što su sveta knjiga, predanja, intuicija i konsenzus verskih učenjaka. Zbog ključne uloge koju razum ima u šiitskoj misaonoj školi, svi pravci u okviru te škole očigledno su racionalniji. Glavne škole islamske filozofije, racionalne teologije, egzegeze i metodologije jurisprudencije ustanovljene su u šiitskom kulturnom ambijentu. Štaviše, možemo kazati da je umerena racionalnost glavna karakteristika šiitske škole i da dva tradicionalna pravca ahbari i tafkiki predstavljaju retke izuzetke u ukupnoj šiitskoj školi mišljenja. Stoga su religijska uverenja, moralne vrednosti i praktične norme ponašanja u šiitskom mislećem sistemu formulisani na znatno racionalnijim osnovama. Iako razum i razumsko razmišljanje nisu bili bitni elementi saznanja u periodu kada su bili prisutni šiitski imami, samim tim što su njihova predanja analizirana kao merilo istine, ipak u periodu kada je imam odsutan razum i sveta knjiga postaju nužni izvori religijskog znanja. Dakle, zaključićemo da umerena racionalnost predstavlja posebnu karakteristiku šiitskog mišljenja u ukupnoj istoriji islamskog saznanja.

Ključne reči: razum, položaj razuma, razmišljanje, šiiti, intelektualno saznanje, umerena racionalnost 